ljtihad: Jurnal Wacana Hukum Islam dan Kemanusiaan

Vol. 20, No. 2 (2020), pp. 175-189, doi : 10.18326/ijtihad.v20i2.175-189

\title{
Circular letter of Aceh's Governor (ad interim) number 450/21770/2019: amid fanaticism and its controversy (content analysis)
}

\section{Zulkarnain}

IAIN Langsa

E-mail: Zulkarnaingure@gmail.com

DOI: 10.18326/ijtihad.v20i2.175-189

The purpose of this research is to discuss the Circular Letter of Aceh's Governor (ad interim) number: 450/21770/2019 concerning "the prohibition of holding recitation other than the i'tiqad Ahlu Sunnah wal Jama'ah which caused controvercy and turmoil of religious life in Aceh because it only allows one understanding of fiqih and prohibits others. This is a normative / doctrinal research using a content analysis approach. The results show that the Aceh Government regulations contained in Circular Letter Number: 450/21770/2019 have brought negative precedents for religious harmony in Aceh, especially the freedom to understand and carry out the understanding of Islam in various madhhab.

Tujuan penelitian ini adalah untuk membahas tentang Surat Edaran Plt. Gubernur Aceh Nomor: 450/21770/2019 tentang "larangan mengadakan pengajian selain dari itiqad Ablu Sunnab wal Jama'ah yang menimbulkan kontroversi, yakni memantik gejolak kehidupan beragama di Aceh sebab hanya memperbolehkan satu faham fiqih saja dan melarang faham lainnya. Penelitian ini termasuk penelitian normative/doktrinal dengan menggunakan pendekatan analisis konten. Hasil penelitian menunjukkan peraturan Pemerintah Aceh yang tertuang dalam Surat Edaran Nomor: 450/21770/2019 membawa preseden negatif bagi perkembangan dinamika kerukunan umat beragama di Aceh, terutama kebebasan untuk memahami dan menjalankan pemahaman agama Islam dalam berbagai madhhab.

Keywords: circular letter; madhbab; fanaticism; madhhab shafi'i. 
Ijtihad: Jurnal Wacana Hukum Islam dan Kemanusiaan, Volume 20, No. 2, Desember 2020: 175-189

\section{Introduction}

On December 13, 2019, which is the $12^{\text {th }}$ of Rabi' al-Akhir $1441 \mathrm{H}$, the Governor of Aceh issued Circular Letter Number: 450/21770/2019 signed by the Acting Governor of Aceh, Ir. Nova Iriansyah, MT. The circular letter was addressed to the regents/mayors in Aceh, the Heads of SKPA (Aceh Apparatus Work Unit), and Heads of Regional Ministries/ Non-Ministries of Aceh Province. The letter is about the prohibition of recitation other than that held by itiqäd Ablus Sunnah wal Jamäah which comes from the law of madhhab Shafi'i. The preamble of the circular letter is Law Number 44 of 1999 concerning the Implementation of the Privileges of the Special Region of Aceh Province, Law Number 11 of 2006 concerning Aceh Government, Aceh Qanun Number 2 of 2009 concerning the Ulama Consultative Assembly, Aceh Qanun Number 8 of 2014 concerning the Principles of Islamic Shari'ah, and Aceh Qanun Number 8 of 2015 concerning Guidance and Protection of Aqidah. Circular Letter Aceh's Governor Number: 450/21770/2019 orders the regents/mayors throughout Aceh, the Heads of SKPA, and the Heads of Regional Ministries/Non-Ministries of Aceh Province to consider the following:

1. The Ulama Consultative Assembly (MPU) has the following duties and authorities:

a. Issuing fatwas whether requested or not on government, development, community, and economic development issues.

b. Giving direction for differences of opinion in society on religious matters.

2. Based on Aceh Qanun Number 01 of 2019 concerning the Aceh Medium-Term Development Plan from 2017 to 2022, the second mission of this plan is to strengthen the implementation of Islamic Shari'ah along with Islamic values and regional culture in people's lives with i'tiqäd Ablus Sunnah wal Jamäab which originates from the law of madhhab Shafi'i while still respecting other schools.

3. To maintain the religious life of the Acehnese people in worship to prevent the development of itiqäd/school of thought/madhbab other than Ablus Sunnah wal Jamäab/ madhhab Shafi'i.

4. The government prohibits recitation/study other than that conducted by itiqäd Ablus Sunnab wal Jamäah and madhhab Shafi'i, and the organizers should consult with the regional MPU and the Heads of SKPA. The regents/mayors should always oversee, 
evaluate, and collect the data of the names of the speakers/preachers/study in their respective agencies.

This research will examine the contents of the Governor of Aceh Circular Number: 450/21770/2019 how the controversy that occurs in Acehnese society also analyzes it using content analysis on religious life with the correlation of civilized freedom and legal hierarchy in Indonesia.

\section{Method}

This doctrinal legal study analyzes the primary data from Circular Letter Aceh's Governor Number: 450/21770/2019 using content analysis method. It is focused on criticizing the contents of the circular letter from the perspective of the school of thought fanaticism, its controversy in the religious life of the Acehnese people, its legislative hierarchy, and tolerance among figh of the school of thought/madhhab.

\section{Controversy and legislative hierarchy problem of Circular Letter Aceh's Governor Number 450/21770/2019}

The dictums in this circular can lead to controversy in the Acehnese society. It was proven that, after fifteen days of signing the letter, there was turmoil in the religious life of the Acehnese people. It caused pros and cons among the Acehnese Islamic community. This is not the first legislative controversy. Previously, there was a regional regulation on polygamy, PUBG game, whipping for non-Muslims, etc. However, this circular letter is the most current among these controversies as stated by the Head of the Aceh Ombudsman, Taqwaddin, in Aceh Journal National Network on Saturday, December 28, 2019. He suggested to the Acting. Governor of Aceh to revoke the circular letter because it is considered to have been regulated in Aceh Qanun Number 8 of 2014. He stated that this circular letter could indicate religious intolerance not only among people of different religions but also among fellow Muslims. In the perspective of the Indonesian Ombudsman, according to Taqwaddin, the regional heads must provide equal services to all recognized religious communities in Indonesia. Besides, they must be just to fellow Muslims in Aceh. He added that the circular letter has the potential to cause discrimination, mal-administration, religious, and 
worshiping intolerance in Aceh (Taqwaddin, 2019: 2).

The con side argues that this circular letter contradicts Aceh Qanun Number 8 of 2014 concerning the principles of Islamic Shari'ah Chapter VI concerning the first section of the Shari'ah concerning worship Article 14 paragraph 3, which reads that the implementation of worship not following the procedures Shafi'i school of thought is allowed as long as it is within the framework of Hanafi, Maliki, and Hanbali schools by always prioritizing harmony, Islamic brotherhood, and peace among Muslims. Article 14 paragraph 4 states that in the event that a community group in Aceh has have practiced the Hanafi, Maliki, or Hanbali school of thought, Shafi'i school of thought cannot be enforced on them. Article 14 paragraph 5 also states that the community group practicing worship within the ideology of religious organizations following the Quran and Hadith authorized by the state is still justified/protected. Furthermore, Article 14 paragraph 7 states that if there is a dissent in practicing worship, then a mudhäkarah or comprehensive study will be carried out by Aceh MPU involving related institutions by promoting the spirit of Islamic brotherhood, tolerance, and openness (Manuscript of Aceh Qanun Number 8 of 2014 concerning Principles of Islamic Shari'ah).

Those who disagreed with the circular letter also argued that the Qanun, which was stipulated in Banda Aceh on October 22, 2014, (27 Dzulhijjah 1435 H) by Aceh Governor, Zaini Abdullah, and included in Aceh Gazette Number 9 of 2014, has a stronger legal basis when compared to the circular letter that only allows Shafi'i school of thought and denies the other Ahlus Sunnah wal Jamäah schools such as Hanafi, Maliki, and Hanbali schools. In the principle of law, there is lex superior derogat leg inferior (lower-level regulation contradicts the higher-level regulation). Referring to this legal principle, the circular letter regarding the prohibition of any recitation other than that of i'tiqäd Ablus Sunnah wal Jamäah which originated from the law of Shafi'i school of thought has lost its function because it contradicts the Aceh Qanun Number 8 of 2014 which is higher in the hierarchy. Based on the legislative hierarchy, the circular letter is contrary to Aceh Qanun Number 8 of 2014 concerning the Principles of Islamic Shari'ah.

An Aceh public policy observer, Nasrul Zaman, added that the circular letter also contradicts the contents of the letter itself. Point 2 cites the mission of the Aceh Mid- 
Term Development Plan (RPJM), which is to strengthen the implementation of Islamic Shari'ah along with Islamic values and regional culture in people's lives with i'tiqäd Ablus Sunnah wal Jamä'ah based on the laws of the madhhab Shafi'i while respecting other schools. On the other hand, point 3 mentions preventing the development of i'tiqad/school of thought/madhab other than Ablus Sunnah wal Jamä'ab/madhhab Shafi'i. In substance, there is an inconsistency between point 1 and point 2. Point 1 explains about permitting for/ respecting other schools of thought, but the next point prohibits other schools except for Shafi'i school (https://www.ajnn.net/news).

Those who agree with the circular letter assume there is no problem with the content of the letter; even, some appreciate the step taken by the Acting Governor of Aceh. The pro side includes MPU and Aceh Regional Party (PDA).

They argue that having faith with Ablus Sunnab wal Jamä'ab in Aceh has been contained in the Regional Regulation for the Special Region of Aceh Province Number 5 of 2000 concerning the Implementation of Islamic Shari'ah in Aceh and Qanun Number 8 of 2014. Meanwhile, the criteria of aqidah Ablus Sunnab wal Jamäah in the Fatwa of Aceh MPU Number 04 of 2011 adopted by Aceh Qanun Number 8 of 2014 Chapter IV Article 9 paragraph 3 should be the concern of the government and used as an additional argument that, historically, Shafi'i school of thought has long been adhered to by the people of Aceh. To date, they could not study the Quran and Hadith more deeply as Imam Shafi'i did, so it is only normal that they follow Shafi'i school. Some argue that this circular letter is needed to unravel the disharmony that has recently occurred in Acehnese society because of the emergence of groups that openly denounce and mislead other Islamic groups.

\section{School of thought (madhhab) fanaticism}

Fanaticism is an ideology or behavior of excessive interest in something. A philosopher, George Santayana, defines fanaticism as multiplying efforts when forgetting about goals (Santayana, 1905: 13) According to Winston Churchill, a fanatical person will not be able to change his mindset and direction. He has strict standards in his mindset and tends not to listen to opinions or ideas that he considers contradicting. There are different types of fanaticism, fanaticism in ethnic, nation, ideology, religion, school of thought, etc. School 
of thought fanaticism is a belief or an excessive belief in a school. Initially, the school of thought (school) was the main idea or basis used by imām mujtabid in solving problems or concluding Islamic law (Shaleh, 2016: 152). Furthermore, the school of thought developed into a group of Muslims who followed the istinbät method of a certain imàm mujtabid or followed the opinion of an imäm mujtahid on issues of Islamic law (Yanggo, 1997: 72).

School of thought fanaticism is allowed as long as it is still inclusive and open to other schools to form logic and an open mind (Abidin, 2020: 67). This fanaticism can turn into a problem when there are exclusiveness, narrowness, and superiority, and considering the school as the most correct one. Exclusive and narrow school of thought fanaticism can lead to a distortion of cognition. Excessive liking of a school of thought can lead to antipathy towards other schools, resulting in a close-minded attitude. The narrow school of thought fanaticism can have negative effects on Muslim community life, such as the polarization of society, faded Islamic brotherhood, faded tasämub attitude, and increasing hatred and antipathy among different schools.

The birth of figh schools with their patterns and characteristics, of course, caused differences of opinion and legal products. The period of the second to the fourth centuries of the Islamic calendar was a period of a massive movement of figh thought across various regions due to the seriousness of Islamic jurists in exploring the law and considerable attention of the Abbasid Caliphs towards Islamic law and Islamic jurists. In this era, Islamic school leaders such as Imam Abu Hanifah, Imam Malik, Imam Shafi'i, and Imam Ahmad ibn Hanbal came up with the idea of a theoretical-methodological framework and the rules of ijtihàd as their basis for establishing law (Sirry, 1995: 61-62). Based on this, the figures and imams of the school of thought do not intend to form a particular fiqh school. However, according to history, the methodologies, theories, and rules formulated have been unwittingly transformed into doctrines or role models to extract law from the source. These theories, methodologies, and principles are increasingly entrenched because the followers of each figure systematize their existence and intrusions their schools as the most appropriate way to perform legal istinbät on various legal cases at hand. Based on the historical incandescent of the birth of these figh schools, a narrow school of thought fanaticism should not exist in the lives of Muslims (Romli, 1999: 2). 
Based on the definition of fanaticism and a brief description of the historicity of the emergence of figh schools of thought, the content of the circular letter seems to contain elements of the narrow school of thought fanaticism or fear of the touch of other schools. This is indicated in points 3 and 4 of the circular letter which limits and prohibits recitation/ studies that are not in line with the ideology of itiqädi and fiqh based on Shafi'i school. The strict dictum in the circular letter will set a negative precedent for the development of the fiqh dynamics of the four schools in Aceh in particular and Indonesia in general.

When examined from the spirit of mutual respect for differences of opinion as exemplified by the founders of the schools of thought, the circular letter directly eliminates tasamuh attitude in the ideology of the school, especially in terms of fiqh.

Sunni Fiqh schools or Ablus Sunnah wal Jamäah are internal independent schools. Nevertheless, historically, there is a clear common thread among them. The relationship is at least a genealogy of knowledge, where three of the four imams of the Sunni schools of thought have a teacher-student relationship (Imam Malik and Imam Shafi'i) and a studentteacher relationship (Imam Ahmad and Imam Shafi'i). Four Sunni Fiqh schools are still developing today, namely Hanafi, Maliki, Shafi'i, and Hanbali.

A. Djazuli in Cik Hasan Bisri explained that the Sunni Fiqh school was initiated from differences of opinion, and then a supporting group, which consisted of imäm mujtahid students, was formed and then developed into the school as known today (Bisri, 2003: 238). The presence of fiqh schools in the mujtahid era was marked by several activities; they are, first, determining a thinking method to understand the source of the law; second, determining the legal terms used in fiqh; third, creating the book of fiqh systematically in chapters and articles, sections and subsections covering all legal issues (Syarifuddin, 1997: 31). From the views of the three figh figures, there are several key concepts in common, namely imam mujtahid, legal ijtihad (istinbät) method, fiqh (Islamic law), and school of thought as figh school. Then, they developed into a community with followers, legal terms, and the making of the fiqh book. These concepts show that there is an anatomy of the school of fiqh as a community. This means that all schools of figh have characteristics and anatomies different from one another. This reality is inevitable. Whether one likes it or not, it has existed and happened in the lives of Muslims (Bisri, 2003: 239). 
From the above explanation, the circular letter is not grounded and is against one of the disciplines in Islamic teachings, namely the comparative science of school of thought or al -muqäranah fi al-madhähib. Besides, point 2 of the circular letter contains the strengthening of the implementation of Islamic Shari'ah along with Islamic values and regional culture in people's lives with i'tiqäd Ablus Sunnah wal Jamäah which originates from the law of Shafi'i school of thought while still respecting other schools. This means that there is a contradiction. Points 3 and 4 prohibit schools of thought other than Shafi'i school while point 2 allows respecting the other schools of figh Ablus Sunnah wal Jamäah, namely Hanafi, Maliki, and Hanbali. The school of fiqh is only a perspective in fiqh which later becomes a community in Islamic society. School of thought is like a river and its small channels that have the same upstream and the downstream in the form of the components of Muslim society. The upstream is the Quran and Hadith while the downstream is the Sunni Muslim community for the followers of مذاهب الاربعة (four schools, namely Hanafi, Maliki, Shafi'i, and Hanbali) (Arfan, 2008: 15-17).

Viewed from the teachings of Imam Shafi'i, the content of the circular letter also has a problem. One of his teachings that can be used as an argument to show fanaticism in only one school of thought and ignoring others is contained in the book of al-Risālah as follows:

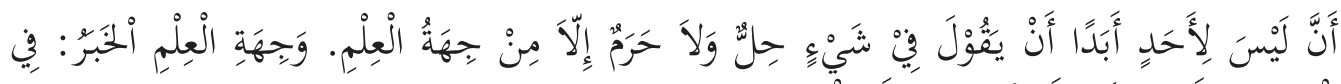

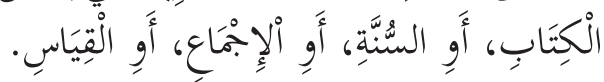

"No one can forever say something is lawful or forbidden except for knowledge. The knowledge is obtained through al-Qur'an or al-Sunnah, or al-Ijma' or al-Qiyas.” (al-Syafi'i, 1308: 39).

In the book of Siyār A'lām al-Nubalā, he says.

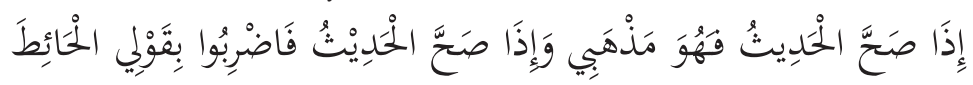

"Authentic hadith is my school of thought, and if there is one (authentic hadith), then throw my opinion to (behind) the wall" (Adz Drababi, 2019: 83).

In the book of I'lāmul Muwāqi'īn, it is stated:

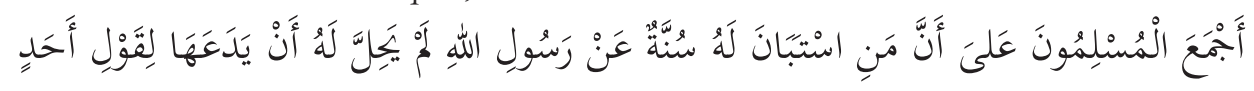

"The Muslims agree that there is indeed anyone who is a sunnab (teaching) of the Prophet, then it is not lawful for them to leave it because of following others' opinions." (al-Jauzy, 2000: 48). 
These excerpts show that Imam Shafi'i is very tolerant of anyone's opinion if it is based on the sunnah and hadith of the Prophet Muhammad.

\section{Interaction between schools of fiqh/madhhab}

Inevitably, the school of fiqh as a school of thought and understanding of fiqh as a personal form of its adherents and as a community will cause interaction in the form of accommodation and thought and social conflicts. In the interaction between thoughts, there may be a rejection of an idea against other alternatives or ideas that have just emerged. It is like in the figh school of thought, so there should not be barriers or restrictions from one school to the others (Fauzi, 2017 : 25), especially for fellow Ablus Sunnah wal Jamäah schools as stated in the circular letter In Islamic fiqh, the ideas or understanding of fiqh can take various forms as a treasure to be grateful for. Thus, it is obvious that the thought and understanding of Islamic figh are very broad and extraordinary. It was exemplified in Imam Shafi'i's rejection of the idea of al-istihsan from Imam Abu Hanifah. On the other hand, Ibn Hazm seemed to reject the idea of qiyās by Imam Shafi'i.

The interaction between the schools of figh in Islam among Ablu al-Sunnah wa al-Jamäah can also take the form of a synthesis of two different ideas as practiced by Imam Shafi'i when compromising the view of ablu al-ra yi initiated by Imam Abu Hanifah with abli alhadìth wal atsār pioneered by Imam Malik bin Anas (Hallaq, 2000: 5).

In Indonesian settings, the form of "compromise" between the various schools of figh can be found in the Compilation of Islamic Law. This is thought to be an attempt to address the disparity in judges' decisions in religious courts. The interaction between schools of figh can also take the form of social relations between communities of schools of thought in solving legal problems that demand quick and accurate solutions. In a school of thought, internal cohesion is also interesting to consider because it is also a product of interaction. If examined more deeply, this internal cohesion has increased significantly when there are differences among schools of fiqh.

The conflicting thoughts among the schools of fiqh can strengthen their internal cohesion. However, cohesion is beneficial when interacting with other school communities. Thus, the wisest attitude is allowing natural selection on these schools of fiqh, by which the 
resilience of thought and understanding of the school of fiqh is more tested and qualified. Academically, the interaction between the schools of figh can be channeled through mudhäkarah, mubāhatsah, intellectual debates, and polemics, or other ways that are elegant, useful, intelligent, brotherhood nuanced, and unemotional. Scientific and critical thinking skills set the pillars that will enliven these activities. The patterns of interaction between schools of thought vary. The pattern can be ikhtiläf (conflict) which takes a long time when it comes to principles or ushüliyyah. It can also be ittifäq (accommodation) if the problem is related to furü'iyah (branch), or it can be a mixed pattern.

Studies on the interaction between schools of figh are very necessary because, first, the understanding of fiqh continues to develop; second, a new approach is needed in the studies of schools of figh to meet the challenges that arise; third, the studies can help organize the comparative studies of schools of thought that are holistic, mondial, and richer from various perspectives more comprehensively; fourth, the studies can become a learning activity in Islamic boarding schools and universities to provide the latest data relating to entities, anatomies, developments, and interactions among the existing schools of figh to students; fifth, the studies can increase tolerance and empathy for the schools of thought, especially the four Sunni schools; sixth, they can be a common reference in formulating the norms of heterogeneous community life through the synthesis of the four existing Sunni schools of thought; seventh, they can be an input in solving socio-cultural problems as a result of differences and contradictions between adherents and followers of schools of thought. All the results of studies on the interaction between schools of figh will be meaningful or advantageous if they can be integrated with other elements. These elements include goodwill, political goodwill, the development design of the school of figh in the future, the ability and expertise of human resources, and maximum support of facilities and infrastructure.

\section{Differences between the schools of fiqh are mercy}

The differences between the sources of knowledge are unavoidable. Many verses of the Quran and Hadith of the Prophet can mean mantūq (editorial-textual), mafhüm (requiring understanding), 'àm (general), khās (specific), majāz (symbolic), haqiqah (fact), mutlāq (unlimited), mujmäl (comprehensive), mubayyan (partial explanation), nāsikeh (eliminator), and 
mansükh (eliminated). All these differences are part of the wealth of Islamic treasures that must be respected and valued. Islam with its ușül fiqh can solve these differences wisely. In ușül fiqh, solving such problems is called al-ta'ärud wa al-tarjīh or al-ta'ärud wal jam'u wa taufíq. In Islam, the differences in furü'iyah (branch) are not something new but have existed since the Prophet's era, emerging the term tanāwu' fi al-Sunnab (diversity in the Sunnah of the Prophet). Thus, the attitude and behavior of the school of thought fanaticism are not right because Islam was born with a tolerance of differences and diversity. Allah SWT (All Glory belongs to Him) has mentioned difference and diversity issues in the Quran surah Fathir verses 27-28:

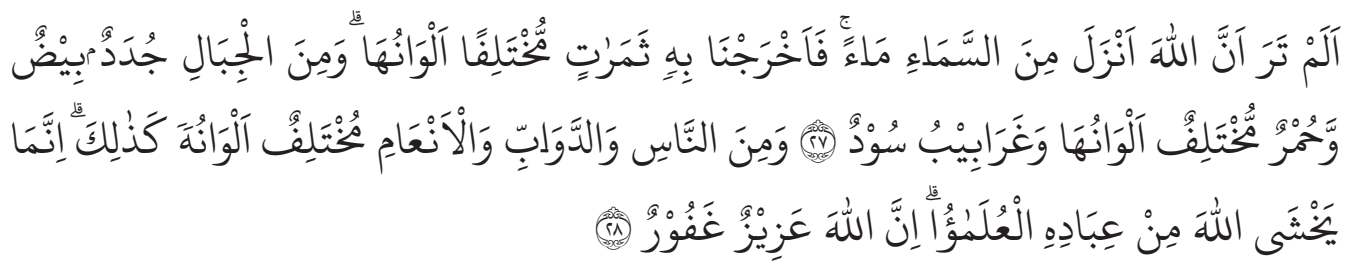

Meaning: Have you not seen that it is Allab Who causes the water to descend from the sky? So, with it We have grown various colorful fruits; and among the mountains are tracks white and red, of different hues, and others dark black. And similarly, the colors of men and beasts and cattle, are different; among the bondmen of Allah, only the people of knowledge fear Him; indeed, Allah is the Most Honorable, Oft Forgiving.

In line with the above verse are surah al-Hujarat verse 13 and surah al-Rum verse 22 . In the Quran, it is also stated that humans have various levels of thinking ability in absorbing knowledge as said by Allah in surah Yusuf verse 76. Imam al-Qurtubī in his book of commentary, al-Qurtubī, explains by quoting the atsar of Ibn Abbas:

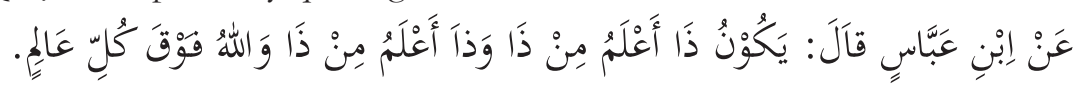

He said: "Among the clever people, there are always those who are cleverer until finally, Allah SWT is the Cleverest of all" (al-Qurtubī, 2008: 199).

Imam al-Nawawi in al-Minhāj fì Sharh Șahīh Muslim bin Hajjāj mentions:

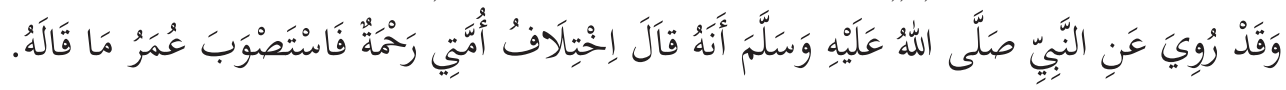
"And it has been narrated from the hadith of the Prophet saying: The difference of my people is a blessing'. And Umar bin Khatab justified about these words of the Prophet." (al-Nawawi, 2004: 91). 
Shaykh Abdurra'uf al-Manawi $(1358 \mathrm{H})$ explained that the word "my people" in the hadith means mujtabid clerics who engage in j̈tihad in furüiyah matters. Imam al-Khatabi explained the difference between the laws of fur' '’ (branch) as follows:

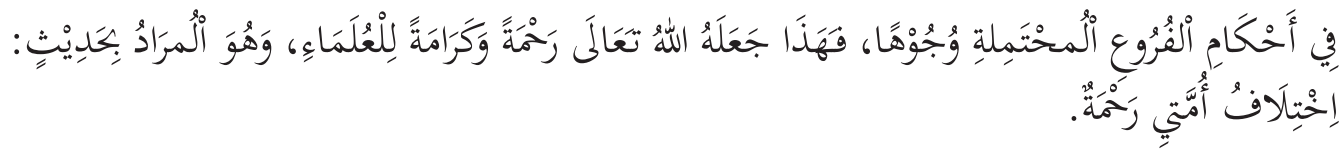

The differences in the laws of furu' (branch) have various interpretations, so the differences in such matters are the mercy of Allah SWT and the honor of the scholars. And that is the hadith means. (al-Manawi, 1358: 92).

Based on this hadith and the explanation of Imam Nawawi and Imam al-Khatabi above, we can understand that the differences of opinions among schools of fiqh that are furu'iyah (branch) are a blessing from Allah SWT to Muslims. Therefore, the desire to uphold only one school of thought like in the circular letter is contradictory and counterproductive. Besides, it is also a principle to remember the existence of kulliyah fiqhiyah rules, namely:

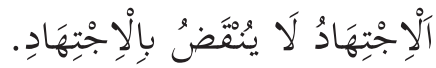

\section{The ijtihad cannot be destroyed (undone)}

These rules imply that all the results of the ijtihad of the mujtabids, especially the absolute mujtabids such as Imam Hanafi, Maliki, Shafi'i, and Hanbali, are valid and cannot be destroyed or nullified. Therefore, there is no justification for a person or a group of people to deny nor prohibit a school of thought that is not theirs as long as it is still within Ablus Sunnah wal Jamäab which is sourced from the Quran and Hadith.

Based on this, the circular letter limits the implementation of the views or ijtihad treasures of various schools in Islam, which is embraced by the people of Aceh, although not as many as the adherents of the Shafi'i school.

\section{Relationship between Circular Letter of Aceh's Governor Number: 450/21770/2019 and social institution of Islamic law}

In Latin, the word institure means establish. From this word, a noun institution is derived, which means establishment. In Indonesian, institution means structure. Judistira K. Garna defines institution as a pattern of behavior that has become commonplace or a form of 
social relationship with a specific purpose. Judistira quotes R.M. Maclver and C.H. Pagl state that institution is an established form or condition of procedural characteristics of group activity (Judistira, 1996: 151-152). Institution or pranata (in Indonesian) is a system of social behavior that is mutually agreed upon or conventional customs in certain societies as well as norms that regulate official social behavior (Hardini, 2009: 6).

The word social institution is derived from English. It regulates behavior and relationship patterns among community members. Thus, social institution is a system of norms to achieve a goal or activity that society deems important. In other words, social institution is an organized system of social relations that apply general values and procedures that regulate and fulfill the main activities of the people. There are three key points in social institution, namely values and norms, permanent behavior (general procedure), and relationship system, the role and status linkage which becomes a medium for carrying out the behavior following the prevailing general procedure.

Kluckhon explains that social institution reflects a society's culture, making it essentially the whole way of human life. In this context, it can be understood that the circular letter is an effort to maintain the tradition of the Shafi'i school of thought in the life of the Acehnese people, as a combination of traditional reactions to challenges and environmental dynamics that continue to develop with various schools. However, please note that, according to Soerjono Soekanto, social institution must be carried out with the following functions:

1. It provides guidance to community members about how to behave for meeting all their needs. The circular letter with mono-loyalty on the Shafi'i school of thought cannot be used as a reference or guide for Acehnese people who do not adhere to this school. It indicates that the social institution has lost its protective function and ethical diversity values.

2. It protects the integrity of society from the threat of community division or disintegration. If examined carefully, the circular letter has the potential to cause division in society because not all Acehnese people have the Shafi'i school of thought. Thus, it seems that there are biological communities (with Shafi'i school of thought) and steppe communities (with Hanafi, Maliki, and Hanbali schools of thought). In the context of the Unitary State of the Republic of Indonesia which has a pillar of Bhinneka Tunggal Ika, it should not happen.

3. It provides guidance in the social control system. This circular letter is very unlikely to exercise social control over all Acehnese people, who are of the non-Shafi'i school of 
Ijtihad: Jurnal Wacana Hukum Islam dan Kemanusiaan, Volume 20, No. 2, Desember 2020: 175-189

thought because they have been marginalized by this circular letter.

Therefore, the relationship between this circular letter and the social institution of Islamic law is counterproductive and can lead to new legal issues in the life of the Acehnese people in the future.

\section{Conclusion}

Based on the explanations, it can be concluded that Circular Letter of Aceh's Governor Number $450 / 21770 / 2019$ has the nuance of the school of thought fanaticism which is narrow and controversial in some ways. The narrow fanaticism is reflected in points 3 and 4 of the circular letter that prevent and prohibit the development of Ablus Sunnab wal Jamäah schools other than Shafi'i school in Aceh. This is due to many factors, including a lack of understanding of the historical background of the birth of figh schools of thought in Islam; lack of understanding of the methodology, theory, and rules used by each school in establishing the law; lack of understanding of the epistemology of the schools of figh. Besides, this circular letter. contradicts the higher provision, Aceh Qanun Number 8 of 2014 concerning the Principles of Islamic Shari'ah Chapter VI concerning the first part of Shari'ah concerning the worship of article 14 paragraph 3, namely the implementation of worship. It does not refer to the procedures of the Shafi'i school of law as long as it is within the framework of the Hanafi, Maliki, and Hanbali schools of thought by always promoting harmony, Islamic brotherhood, and peace among Muslims.

\section{Bibliography}

Books and Journals

Abidin, M. Zaenal. "Pentingnya Bermadzhab dan Larangan Fanatisme Menurut Pandangan KH. Hasyim Asy'ari.” Jurnal Permata, Vol. 1, No. 1 (2020): p. 58-71.

Arfan, Abbas. Geneologi Pluralitas Mą̧hab dalam Hukum Islam. Malang: UIN Malang Press, 2008.

Bisri, Cik Hasan. Model Penelitian Fiqh: Paradigma Penelitian Fiqh \& Fiqh Penelitian. Bandung: Kencana, 2003.

Fauzi. "The Interactions of Madzhabs in Aceh: A Tripolar Typology." Jurnal Miqot, Vol. XLI, No. 1 (2017): p. 20-40. 
Garna, Judistira K. Ilmu-Ilmu Sosial Dasar-Konsep-Posisi. Bandung: Universitas Padjadjaran, 1996.

Hallaq, Wael Baljak. Sejarah Teori Hukum Islam, Pengantar Ushul fiqh Madz̧hab Sunni. translated by E. Kusnadiningrat dan Abdul Haris bin Wahid, Jakarta: Raja Grafindo Persada, 2000. Hardini, Tri Indri. "Model Pembelajaran Jarak Jauh Bahasa Indonesia bagi Penutur Frankofon Melalui Teknologi Multimedia", Disertasi Sekolah Pascasarjana, Universitas Pendidikan Indonesia, Bandung, 2009.

al-Manāwi, Muhammad Abdurrā’uf. Fayḍ al-Qadìr, Sharh al-Jāmi’ al-Saghìr. Kairo: Maktabah Tijāriyah Kubrā, $1356 \mathrm{H}$.

Nawawi, Imam. al-Minhāj fì Sharh Șahīh Muslim bin Hajjäj. Libanon: Dār al-Arāfah, 2004.

Shaleh, M. “Eksistensi Madzhab dalam Hukum Islam Masa Kontemporer.” Jurnal Hukum Istinbath, Vol. 13, No. 1 (2016): p. 149-163.

Santayana, George. Life of Reason; Reason in Common Sense. New York: Charles Scribneris Son, 1905.

SA, Romli. Muqaranah Madzabib Fil Ushul. Jakarta: Gaya Media Pratama, 1999.

Sirry, Mun'im A. Sejarah Fikih Islam. Surabaya: Risalah Gusti, 1995.

al-Syafi'i, Muhammad Ibn Idris. al-Risālah. Mesir: al-'Ilmiyah, 1308 H.

Syarifuddin, Amir. Ushul Fiqih Jilid I. Jakarta: Logos Wacana Ilmu, 1997.

Yanggo, Huzaemah Tahido. Pengantar Perbandingan Madæ̧hab. Jakarta: Logos Wacana Ilmu, 1997.

al-Jauzy, Ibnu Qayyim. I'lämu al-Muawàqi'in. translated by Asep Saefullah dan Kamaludim S, Jakarta: Pustaka Azzam, 2000.

\section{Regional laws and regulations}

Aceh Qanun Number 8 of 2014 Chapter IV Article 9 about the Principles of Islamic Shari'ah.

Circular Letter of Aceh's Governuor Number: 450/21770/2019

\section{Newspaper}

Aceh Journal National Network, December 28, 2019

https://www.ajnn.net/news accessed on July 28, 2019 
